\title{
The transformation of detention in Romania: from exile to main punishment
}

\author{
Cristina llie Goga \\ University of Craiova, Str. A. I. Cuza, No. 13, Craiova, Romania \\ E-mail address: cristin_il@yahoo.com
}

Keywords: Romanian detention system, punishment, the Middle Ages, the Modern Age

\begin{abstract}
The article aims to analyze the evolution of detention on the Romanian territory, during the periods of its transformation from exile to a form of punishment, namely the Medieval and Modern Ages. We noticed that, although there was always detention as a form of restraint of the perpetrator until the application of other punishments and rarely as a form of punishment, the deprivation of liberty in prisons became, only in the eighteenth and nineteenth centuries the main form of punishment. We will initially analyze the methods of punishment used in Romanian Medieval period and the locations of detention ("mines", "dungeons", "bulk", "hearth" or "monastery") and then, will follow their transformation in modern detention areas.
\end{abstract}

\section{INTRODUCTION}

Previously analyzing, the development of penalty systems, globally (Goga, 2015: 183-194) and in Romania (Goga, 2015: 229-237), we noticed that although there was always detention as a form of restraint of the perpetrator until the application of other punishments and rarely as a form of punishment, the deprivation of liberty in prisons became, only in the XVIII ${ }^{\text {th }}-\mathrm{XIX}^{\text {th }}$ centuries the main form of punishment (Ilie, 2015: 21).

Hard labor in mines or salt mines is found from the Dacia province (Serban, 2011: 42-45), but the first clear evidences on places of detention on Romanian territory dates from medieval times. In that period, the detention spaces were "mines", "dungeons", "bulk", "hearth" or "monastery" and punishments could be for life or for a specified period. However, as Gr. I. Dianu mentioned, back then, prisons were places of suffering and torture (Dianu, 1900: VIII) with a obvious repressive character.

We can talk about a debut of what it means today deprivation of liberty in penitentiary, along with the appearance of the first elements of "humanization of punishment", namely, with the advent of the Organic Regulations promulgated in 1831 in Wallachia and in 1832 in Moldavia, which required the "humanization" of conditions in the detention system.

\section{DETENTION IN ROMANIA IN THE MIDDLE AGES}

For the Romanian territory, the period covered by the Middle Ages is a very controversial one in terms of temporal delimitation and we find the medieval age as covering the period from the years 275/527 and 1541 (the beginning of dependence towards the High Porte) (Giurescu, 1946) or the period between the $18^{\text {th }} / 19^{\text {th }}$ centuries to the early $19^{\text {th }}$ century (the movement of Tudor Vladimirescu) (Constantiniu, 1997).

In terms of the evolution of the punishment systems, we consider the $3^{\text {rd }}$ century AD as the beginning of the medieval period. In the millennium which covered the period of the great migratory waves there are formed the primary feudal relations, outlining the social and economic differentiation, with noble and peasant classes and the princes and voivodes were the liders of the local subjected population, having judicial rights (Chis,, 2012: 57-58). Within the villages, they go from the organization of large families headed by pater familias, who decided the sentencing, to individual families (preponderant in medieval society) and the judicial powers of the village and decisions on sentencing belonged to a „council of elders”. 
In early feudalism, the punishment for illegal acts is applied in the village community on the principle of private vengeance and retaliation law (Fotino, 1925), the joint responsibility of the entire parish intervening only if they had to repair the damage of another parish. All cases were judged by a ,judge” (jude) or the institution of the „council of elders” (good and elderly people), who decided the punishment and its implementation (Chis,, 2012: 95). In that time it was applied the „law of the country" also called the „law of the land" which was an unwritten law, the judgment being made by „law and justice” (Chiş, 2012: 97-98).

In the developed feudalism there are formed the Romanian feudal states like Wallachia, Moldovia, Transylvania Voivodeship, and the Country of Caravna.

The princes of Walachia, Moldovia and Transylvania had judicial powers, being even the supreme court in civil and criminal cases, in causes of treason and embezzlement and having the right of judgment on his subjects. He was able to judge ultimately, retract its own decision, forgive the guilty, condemn to death for "treason", issue any penalty, advice the judges on ways of judging. Princes had absolute powers, being able to condemn a person to death even without being judged, the guilty thus becoming ,victims of revenge” (Dianu, 1900: 10-11).

In Wallachia and Moldovia judgment was done by consulting the Lordly Council, later called Imperial Council ('Divan"), but the decision was still given by the prince.

In Transylvania, when the organization form became the Principality, the Prince had supreme judicial power, but could grant delegation, ius gladii, to some governors for their parishes, representing the possibility of punish with death. The prince could also amnesty, pardon or commute punishments. In Transylvania we also find the institution called "Diet" that included certain judicial powers (Chiș, 2012: 109-113).

Locally, justice was also exercised by feudal, secular or religious lords (senior clerics), for their subjects.

In Transylvania, due to the diversity of populations but also the administrative organization, we find another organization of judiciary power, all courts having the name of „Throne”, but having distinct functions (Chiş, 2012: 134-138).

At the beginning of feudalism the ruling procedure of judicial decision was oral, subsequently becoming written and more elaborate (Chiș, 2012: 149-152).

Punishment during the feudalism period was of four types:

Corporal punishment. They consisted in death punishment by beheading, hanging, placing into forks, hitting with the mace, impaling, drowning, burying alive, burning alive or punishment that brought bodily prejudice like beatings, mutilation, torture based punishment.

Imprisonment punishment. In that time we find detention places such as „mines”, „dungeons”, „bulk”, „hearth” or „monastery” and the punishment could be for life or for a specified period (Băla, 2011: 18-20). G. Dianu says that detention was prior to death, because people sent to prison rarely got out alive.

Pecuniary punishment. These penalties were many and thus we find "dușegubania" (collective criminal responsibility for crimes such as murder, robbery, theft, incest, adultery), property confiscation for the use of victims or the lordship, „gloaba” (fines in cash or in kind). There was the possibility, for people who committed less serious offences and were punished to death, to redeem their life by „,blood pay”, which was the payment of „compensation" and a „royal tribute” (Dianu, 1900: 7-8).

Accessory punishment. These had different forms such as: the loss of noble quality, binding on the pillory, torture, civic degradation, asking for forgiveness under shameful circumstances etc. (Chiș, 2012: 170-171).

The first written documents that refer to punishments and their execution mode were called "codices" and appeared in the $16^{\text {th }}$ and $17^{\text {th }}$ centuries (The Codex from Putna- 1581, Codex from Bistrița Monastery - 1618, Codices from the Bistrița, Oltenia și Galați monasteries- $17^{\text {th }}$ century), representing ,the royal commands" with secular and religious nature for the clerics and „laymen” (Chis, 2013: 122-123). Also there appeared in the $16^{\text {th }}$ century, at the monasteries of Moldavia and 
Wallachia, Slavonic manuscripts representing the „divine” rules for the benefit of judicial processes (Vălimărescu, 1999: 85-91; Grecu and Panaitescu, 1994).

The most important manuscripts from the Romanian Middle Ages, where we find incipient elements of criminal execution law, are considered to be: the "Minor Codex" in 1640 during the reign of Matei Basarab; „The Romanian book of teaching of royal codices” in 1646 during Vasile Lupu; the „Major Codex” in 1652 during Matei Basarab; the „Royal decrees” of the Hungarian king and laws developed by the Transylvanian Diet (Gorescu, 1930: 3). After the implementation of these codices, all punishment for acts committed, was made following the text of the law. However, the punishments were cruel and harsh (disfigurement, beatings, murder), and equality before the law was not respected, the manorial class being priviledged (Dianu, 1900: 14-15).

During the end of feudalism (the end of $18^{\text {th }}$ century - early $19^{\text {th }}$ century), works appear which are particularly important in criminal law and punishment execution, such as statutes from Wallachia ("Codex Registry"- 1780,"Caragea statutes" - 1818) (Camariano, 1955: 86-95) and Moldavia ("Criminal registry" - in 1820 under the reign of Scarlat Calimah, "Codex ordinances to investigate criminal acts"-1820 published under the reign of Mihail Șuţu; Criminal registry- 1826 that appeared the reign of Ioan Sandu Sturza) (Dobrilă, 2012: 64). However, the changes made by those previously mentioned acts do not bring big changes in the sense of visible moderation of the heinous manner of punishment execution (Dianu, 1900: 12).

\section{DETENTION IN ROMANIA IN THE MODERN AGE}

The modern age lies in Romania, according to professor Constantin Giurescu from 1541 until 1821 (the national and social movement of Tudor Vladimirescu) (Giurescu, 1946) and according to the historian Florin Constantiniu it lasts from early $19^{\text {th }}$ century (the movement of Tudor Vladimirescu) until the early $20^{\text {th }}$ century (Conference in Paris, 1919-1920) (Constantiniu, 1997).

We consider the onset of modernism in criminal law since the first elements of "humanization of punishment", namely the $19^{\text {th }}$ century, with the advent of the Organic Regulations promulgated in 1831 in Wallachia and in 1832 in Moldavia, which required the "humanization" of the conditions in the detention system (safety and cleanliness in detention places, food, clothes, light and heat for prisoners) and the punishments (the ban of "tortures" and repealing of "disfiguration") (Chiș, 2013: 123-125). These Organic Regulations creates "rules in prisons for Muntenia" and regulations, decisions and anaphoras in detention for Moldavia (Gorescu, 1930: 8).

There was back then six jails: 2 corrective ones, 2 confinement ones, 2 of forced labor for life or for a specified period. Also, there were 14 county jails, which were funded by municipalities or city councils. The exiled people executed their sentences in monasteries (Gorescu, 1930: 11-12).

In Moldavia, between 1832 and 1862, the detention places were under the administration of the "Royal governor"(Armașul) and "President of the Prison for Criminals" (Președintele Criminalului). We find in this region 13 county prisons, in Iași police custody and the "Prison for Criminals"(Criminalul) and in Târgu-Ocna a hard labor prison. The conditions in these detention facilities were very bad, especially until the reign of Grigore Ghica, who in 1850, after a report presenting the prison conditions, requested modifications and repairs in the prison of Iași, construction of a building for the detention of prisoners in Târgu-Ocna and installation of county prisons in private houses (Gorescu, 1930: 13-17).

In 1841, during the reign of Alexandru Ghica, there appears an addition to the Caragea statutes representing a form of Criminal Code, and in 1851, during the reign of Barbu Ştirbei, there appears a form of the Code of Criminal Procedure, "Criminal registry", being a juxtaposed and imporved study.

In this registry we find the punishments applied during that period, making a differentiation between criminal punishments and correctional ones, as it follows:

- "Criminal" punishments were: death, hard labor in prison (for life or for a period between 5 and 15 years), imprisonment with labor in detention center (for sentences ranging from 5 years to 1 
year and a half); imprisonment without work (between 10 years and a year and a half); beating of 50 to 150 rods; citizens' degradation;

- Correctional punishments were: imprisonment from six days to 2 years; beating of 25 to 50 rods; prohibition of some civil or family rights for a specified period; fining (globirea) (Chiș, 2013: 127-128).

In 1862 it was organized for the first time the prisons service in Romania, by Regulation approved by Royal Decree No. 630 in August. This regulation provided the following types of prisons: preventive; correctional for the ones sentenced to 6 days to 2 years; of reclusion to forced labor in mines (for life or limited period); of reclusion to easier forced labor; correctional for youth from 8 to 20 years; of reclusion for women. On the other hand, the regulation also sets out the types of establishments of charity: for crippled beggar women and men; for abled beggars; for young orphans (Gorescu, 1930: 18).

In 1862 we find six prisons and two penitenciaries. Later two prisons were established for correction, one for reclusion; one for vagrants and three prisons. In the period 1862-1874 there were established a tannery factory and workshops (cardboard, leather, shoemakers, etc.) in 5 locations (Gorescu, 1930: 20-21).

During the reign of Alexandru Ioan Cuza, on $21^{\text {st }}$ of April, 1864 the Criminal Code was enacted, entering into force on the $1^{\text {st }}$ of May of 1865, along with the entry into force of the Criminal Procedure Code. The code has been adjusted over the coming years as it follows: in 1874 (109 articles are modified), 1882, 1893, 1894 and 1895 and in 1912 is republished.

The Criminal Code of the United Principalities published on $30^{\text {th }}$ of October of 1864 distinguishes from Article 1 between three types of offenses: "crimes", "faults" and "contraventions" and punishments applied for them, such as:

- For "crimes" the following punishments were applied: forced labor (for life or for limited period between 5 to 25 years); reclusion (closing in a labor house) (for a period between 3 and 10 years); detention (in monasteries from 3 to 10 years) and civic degradation (applied from 3 to 10 years) (Criminal Code, 1864: Art. 1, 7, 10-23);

- For "misdemeanors" there were applied: correctional prison (executed in correctional house where the prisoners were used for work, for a period between 2 years and 6 days); prohibition of some political, civil, or family rights (from 3 years to 6 months) and a fine from 26 lei upwards (Criminal Code 1864: Art. 1, 8, 24-28);

- For "contraventions"there were applied: police prison (in arrest homes without being used for work and were applied for a period between five days and one day) or police fine (up to 25 lei) (Criminal Code 1864: Art. 1, 9, 29-30).

Although the Criminal Code of 1864 did not mention death penalty, this punishment is found in the Military Justice Code of 1881, but only for soldiers and commanders who surrendered or were leaving the stations (Military Justice Code: 1881, Chapter II Apud. Truică, 2013).

While in the United Romanian Principalities there were applied the Codes from 1864/1865, in Transylvania it was apllied the Hungarian Criminal Code entered into force in 1880, in Bucovina the Austrian Criminal Code of 1852 and in Basarabia the Russian Criminal Code of 1903 (Filitti and Vrăbiescu, 1938: 403).

In 1874 there came into force the Law on the regime of prisons, law that was applied for a period of 55 years, until the entry into force of a new law on the organization of penitenciaries. By its elements of novelty, the regulation was considered one of the most progressive of that time (Durnescu, 2008: 10). Prisons were divided into two categories: a) for persons preventively arrested-"preventive prisons" (for misdemeanors and crimes) and b) "prisons of doom" (prisons for those forced to labor; reclusion prisons; detention prisons; correctional and police jails) (Dianu, 1900: 77-79). All prisons had sectors for "women, men, adults and minors, with no communication between them" (Law on the regime of prisons, 1874: Art. 2).

In enforcing the law, the focus was, besides the rehabilitation concerns (education, religious service) (Gheorghiţă, 2013: 23; Niţă, 2011: 63), on the development of workshops and the 
systematization of prisoners' activity according to its nature in: working in state workshops, working in particular of prisoners and working in salt works. The work in particular of prisoners was organized in 1896 under an ordinance from the General Director of prisons (Brezeanu, 2007: 272).

In the law of 1874, we find an early element of the institution of "release on parole", but only for the minors who were detained in correctional education homes. Thus, those who had good behavior could drop out of the deprivation of freedom system "at the request of some individuals that provided guarantees for the execution of the punishment", the minors being sent for education, in addition to farmers or craftsmen, being given the "moral wanted conditions". However, the administration could bring the minors back to the correction house (Sorescu, 2015: 27) if it found a deviation from the basic conditions (Chiş, 2013: 133).

On January $1^{\text {st }}$, 1930 , when the law of 1874 ceases to have effects, we find in Romania 28 county sections of preventive arrest and 54 penitenciaries and preventive prisons, divided as it follows:

- 23 central prisons (Aiud, Brașov, Bucovăț, Caransebeș, Cernăuți, Chișinău, Cluj minori, Constanța, Craiova, Doftana, Focșani, Galați, Gherla (correctional), Iași, Mărgineni, Mislea (women), Ocnele Mari, Oradea, Satu-Mare, Suceava, Tg. Ocna, Văcărești, Slănic);

- 23 prosecution prisons(Alba, Arad, Câmpulung, Severin (Lugoj), Ciuc, Cluj, Făgăraș, Hunedoara (Deva), Maramureș (Sighet), Mureș (Tg. Mureș), Năsăud (Bistrița), Odorhei, Caraș (Oravița), Rădăuți, Sălaj (Zalău), Sibiu, Someș (Dej), Strojineț, Târnava Mare (Sighișoara), Târnava Mică (Dumbrăveni), Timiș (Timișoara), Trei Scaune (Sf. Gheorghe), Turda);

- 8 preventive prisons (Bălți, Cahul, Cetatea Albă, Hotin, Ismail, Orhei, Sorova, Tighina) (Gorescu, 1930: 48).

\section{CONCLUSION}

Analyzing detention and punishment on the Romanian territory in the Middle Ages and Modern Age we notice that it had an evolution, in the direction of its modification from the Medieval period, when it was used as a form of exile combined with torture modalities (Goga, 2015: 300) or it was a penalty preceding death, to a pure form of punishment by creating laws that have modernized detention places and have removed corporal punishment in prisons and penitentiaries.

\section{Acknowledgment:}

"This work was supported by the strategic grant POSDRU/159/1.5/S/133255 Project ID 133255 (2014), cofinanced by the European Social Fund within the Sectorial Operational Program Human Resources Development 2007-2013”.

\section{References:}

[1] I. Băla, Evoluția sistemului de executare a pedepselor privative de libertate în dreptul românesc. Universul Juridic, Bucharest, 2011.

[2] O. Brezeanu, The crisis in the prison system. Revista de criminologie, de criminalistică și de penologie. Journal of criminology, criminologicol science and penology. 1 (2007) 270-287. Retrieved from: www.criminologie.ro/SRCC/CDs/2007/2007-01/Criza\%20din\%20sist.penitenciar.doc .

[3] I. Chiş, Istoria dreptului și statului românesc, Universul Juridic, Bucharest, 2012.

[4] I. Chiș, Drept execuțional penal, Universul Juridic, Bucharest, 2013.

[5] Criminal Code of the United Principalities published on $30^{\text {th }}$ of October, 1864 in the Official Monitor. Retrieved from: http://idrept.ro/DocumentView.aspx?DocumentId=00040047 . 
[6] F. Constantiniu, O istorie sinceră a poporului român. Bucharest: Universul, 1997.

[7] Gr. I. Dianu, Istoria închisorilor din România. Studiu comparativ: legi și obiceiuri, Tipografia Curții Regale F. BÖBL FII, Bucharest, 1900.

[8] M. C. Dobrila, Evoluția istorică a reglementării infracțiunii de înșelăciune, Analele Științice ale Universităţii ”Al. I. Cuza” Iași- Tomul LVIII, Științe Juridice. 2 (2012) 47-72.

[9] I. C. Filitti, G.Vrăbiescu, Legislația penală, in D. Gusti (coord.) Enciclopedia României. Vol. IStatul, Asociația Știinţifică pentru Enciclopedia României, Bucharest, 1938.

[10] G. Fotino, Contribution à l'étude des origines de l'ancien Droit coutumier roumain: un chapitre de l'Histoire de la Propriété au Moyen Age, Duchemin, Paris, 1925.

[11] V.I. Gheorghiță, Religious behavior of Romanians, Universitary Journal of Sociology, 1 (2013) 23-27.

[12] C. I. Goga, Historical evolution of punishment systems. Analele Universităţii din Craiova. Seria Istorie, 27 (2015) 183-194.

[13] C. I. Goga, Exegetical and doctrinal perspectives on punishment. Humanities and Social Sciences Review, 04/01 (2015) 297-303.

[14] C. I. Goga, Recent Approaches to Criminal Policies in Romania: Critical Overviews and Local Inputs. Revista de Științe Politice. Revue des Sciences Politiques, 46 (2015) 229-237.

[15] C. Giurescu, C. Istoria românilor din cele mai vechi timpuri până la moartea regelui Carol I. Cugetarea-Georgescu Delafras, Bucharest, 1946.

[16] O. Gorescu, "Văcăreștii” Mânăstire. "Văcăreștii" Penitenciar. Precedat de un scurt istoric asupra regimului penitenciar în România, Unknown publishing house, Bucharest, 1930.

[17] A. Grecu, P.P. Panaitescu, Începuturile dreptului scris în limba română. Studii VII, Lumina Lex Publishing House, Bucharest, 1944.

[18] C. Ilie, „De jure“ and „de facto“ situation in the detention system. Case study: Romania. Journal of Arts and Humanities, 4/2 (2015) 20-28.

[19] Law on prison regime from 1874 (sanctioned by Royal Decree no. 169 of $26^{\text {th }}$ of January 1874).

[20] A. Niţă, Cultural phenomena and processes in contemporary society-determinants of cultural policies. Revista de Științe Politice. Revue des Sciences Politiques, 32 (211) 61- 69.

[21] E.M. Sorescu, Romanian Social Work Education - History, Standards and Perspectives. Revista de Asistență Socială, 1(2015) 23-34.

[22] I. Şerban, The Greek and Latin cultures reflected in modern Romanian culture. Revista de Stiinte Politice. Revue des sciences politiques, 29 (2011) 42-45.

[23] P.Truică, The evolution of the crime field in the military discipline and order from crimes and delicts against military obligations to penal crimes against the capacities of the armed forces in missions of national defense. Aspects of comparative law. Romanian Association of Humanitare Law. Prahova`s Branch (2013). Retrieved from:

http://www.arduph.ro/domenii/jurisdictie-penala-internationala/evolutia-sferei-infractiunilor-laordinea-si-disciplina-militara/ .

[24] A. Vălimărescu, Tratat de enciclopedia dreptului, Lumina Lex, Bucharest, 1999. 